\title{
REMOTE SENSING AND GEOBOTANICAL PROSPECTING IN FINLAND
}

\author{
JOUKO TALVITIE
}

\begin{abstract}
TALVITIE, JOUKO 1979: Remote sensing and geobotanical prospecting in Finland. Bull. Geol. Soc. Finland 51, 63-73.

Visible and near infrared radiation is reflected from vegetation and open vaters in Finland in summertime. Thus the variation in the intensity measured is primarily an informant of the variation in vegetation. Indirectly it is also a geological informant and therefore the botanical classification of intensity data is also geological by nature in a terrain in its natural state.

For geobotanical prospecting of unexposed bedrock two extreme cases have been presented. In the first case the lithology keeps constant but the bedrock topography and the superficial geology vary. Thus, the primary component recognized is the type of vegetation and the secondary one the superficial geology. The third component, the relative variation in soil thickness can be estimated through the stratigraphical sequence number of the topmost formation prospected, and the figures or patterns of figures in bedrock topography and correlative structures may be interpreted.

In the second case there is an extreme variation in lithology, silicate - carbonate rocks, a slight variation in topography but the overburden remains rather constant. Now, a specific type of vegetation thrives above each lithological unit and the carbonate complex, for instance, can be prospected.
\end{abstract}

Jouko Talvitie, Geological Survey of Finland, P.O. Box 237, SF-70101 Kuopio 10, Finland.

\section{Introduction}

Basic research in geobotanical remote sensing has been done at the University of Oulu on funds provided by the Academy of Finland. The purpose of this research has been to investigate, on one hand, the variation of visible and near-infrared radiation reflected by the ground and, on the other hand, the variation in the intensity of long or thermal infrared radiation emitted by the ground and the correlation of this variation with that of known geological units. In the present paper are reported the results, primarily, that were obtained from the sensing of reflected radiation.

The radiation data recorded on digitized tapes originated from the four-channel LANDSAT-1 and two 11-channel airborne scanners. Thus could the radiation properties of ground targets be investigated not only by means of individual channels but also in the spectral sense through multi-channel analysis. The supervised and automated pattern recognition program used was the RECOG with color-TV display, which in Finland is available at the State Technical Research Centre. 


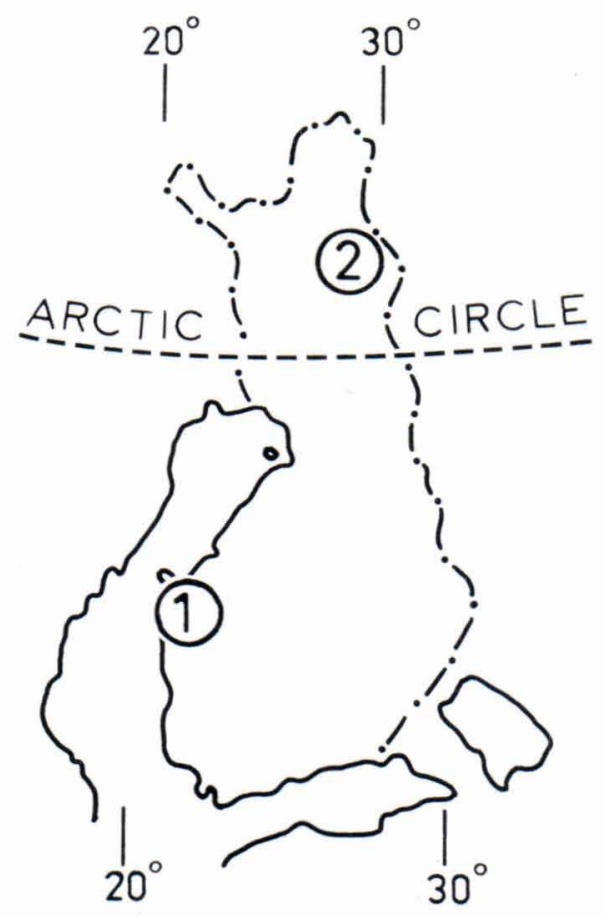

Fig. 1. Location of study areas 1 and 2.

\section{Posing the geological problem}

Two areas were investigated (Fig. 1). Area 1 is located in the level Bothnian coastal region. Available here were both LANDSAT1 and airborne data (Bendix scanner, resolution angle $2.5 \mathrm{mrad}$, flight altitude $3 \mathrm{~km}$ ). Shown in Fig. 2 is a stratigraphic sketch, which depicts the set of geological problems posed by Area 1:

1. The bedrock is composed of migmatites (gneisses) and salic orogenic plutonic rocks. It is therefore fairly homogeneous, but only slightly exposed. The landscape thus shows up, in the main, only the structural and topographic features of the bedrock.

2. Variation is apparent mainly in the overburden, which reveals the following stratigraphic sequence: bedrock, basal till, beach deposits, silts-clays and peat. The till shows strong evidence of glacial transport.
Area 2 is located (Fig. 1) in the Sokli section of the Savukoski district, from where only airborne data are available (Daedalus scanner, resolution angle $2.5 \mathrm{mrad}$, flight altitude $6.7 \mathrm{~km}$ ). The place is located in the hilly part of Finnish Lapland, and the geological conditions are essentially different from those prevailing in the other area investigated (Fig. 3).

1. The bedrock exhibits extreme variation: formations of carbonatite and phosphorite rocks - formations of silicate rocks. Exposures are lacking.

2. The overburden consists predominantly of till, varying from one to ten meters in thickness. It has been subjected only to slight glacial action. Overlying the till are some sandy deposits of glaciofluvial origin, and in many places in valleys there occur thin layers of peat.

Area 2 has its ore-prospecting aspect, the separability of the silicate rocks from the formation of carbonatite and phosphorite and, on the other hand, the separability of phosphorus ore from carbonatite.

This part of the study will be dealt with in the following, therefore, in greater detail. in addition, Area 1 has been described earlier as a partial result of this theme (Kilpelä et al. 1978).

\section{Area 1: Geobotanical result}

A summary of the geobotanical results of the investigations carried out in Area 1 is presented in Table 1. It explains the geobotanical factors operating in the terrain in its natural state as represented in the stratigraphic profile reproduced in Fig. 2. At the left in the table are the geological units of the area, and at the right, correspondingly, the prevailing type of vegetation. The table shows that the variation in the surficial geology conforms systematically to the varia- 


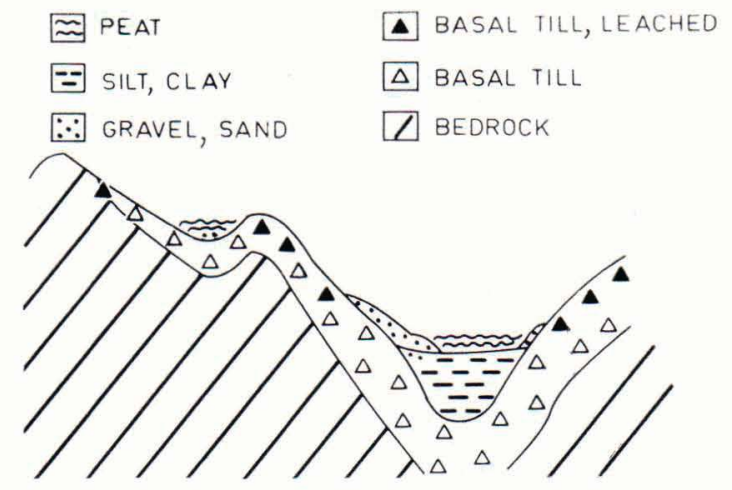

Fig. 2. Stratigraphic sketch of study area 1.

tion in the type of vegetation. In the middle of the table is set forth the correlation to the topographic situation (elevation), humidity and daytime temperature of the ground surface as well as to the thickness of the overburden.

Inasmuch as the ground in Finland in its natural state is normally covered with vegetation, the reflected radiation carries direct data only concerning the variations in vegetation. The surficial geology and other factors mentioned in Table 1 can be charted on the basis of reflected radiation only indirectly by reference to the geobotanical correlation presented - in short, considering them as secondary factors from the standpoint of prospecting.
The remote sensing performed in accordance with the scheme set forth in the foregoing succeeded well. Only sand beds composed a category of formations the position of which in the table is uncertain. But if the natural state is disturbed, the diagram drawn (Table 1) loses its significance.

The country rock in the area is fairly homogeneous, granitic-granodioritic; accordingly, lithological diversity could not be observed to cause any variation in the vegetation. The assumption was made, however, on the basis of observations made elsewhere in the terrain, that if any noteworthy lithological differences occur in the bedrock, they are likely to appear as variations in the vegetation, notwithstanding the nature of the overburden. "Anomalous» rock units of this kind could thus be prospected by means of remote sensing. It would facilitate the success of prospecting if the till had undergone a minimum of glacial transport.

\section{Area 2: Geobotanical prospecting of Sokli carbonatite}

\section{Data acquisition}

The survey fligth over the area was made with an 11-channel Daedalus scanner on July

Table 1. Geobotanical correlation observed in a terrain in its natural state. The arrows show into which direction the elevation, moisture and daytime temperature of the ground and the thickness of the overburden are relatively increasing.

\begin{tabular}{|c|c|c|c|c|c|}
\hline \multicolumn{5}{|c|}{ Secondary factors } & Forest type \\
\hline $\begin{array}{l}\text { Precambrian bedrock } \\
\text { Boulder field-till } \\
\text { Loose basal till } \\
\text { Tight » } \\
\text { (Sandy outwash) } \\
\text { Silt } \\
\text { Peat }\end{array}$ & 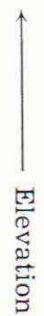 & 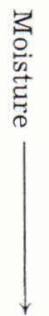 & 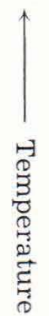 & 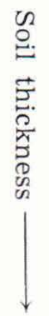 & $\begin{array}{l}\text { Dry heath } \\
\text { Partly heath } \\
\text { Moist heath }\end{array}$ \\
\hline
\end{tabular}




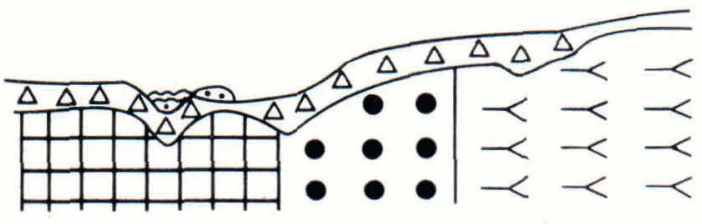

$\begin{array}{ll}\approx \text { PEAT } & \square \text { CARBONATITE } \\ \therefore: \text { SANDS } & - \text { FENITE } \\ \triangle \text { TILL } & -- \text { GNEISSOSE GRANITE }\end{array}$

Fig. 3. Stratigraphic sketch of study area 2 .
5,1977 , at $2.13-2.45$ p.m. The band widths of the channels are shown in Fig. 5 a. The lines of flight ran straight toward the sun, with the sky cloudless. The minimum size of the ground element, at the nadir, was $h \Theta=$ $6.7 \mathrm{~km} \times 2.5 \mathrm{mrad} \sim 17 \mathrm{~m}$. The total angle of view of the scanner, which determines the length of the strip scanned in the terrain, was $\psi=87^{\circ}$. The investigation showed that the scanner data obtained were valid for geo-
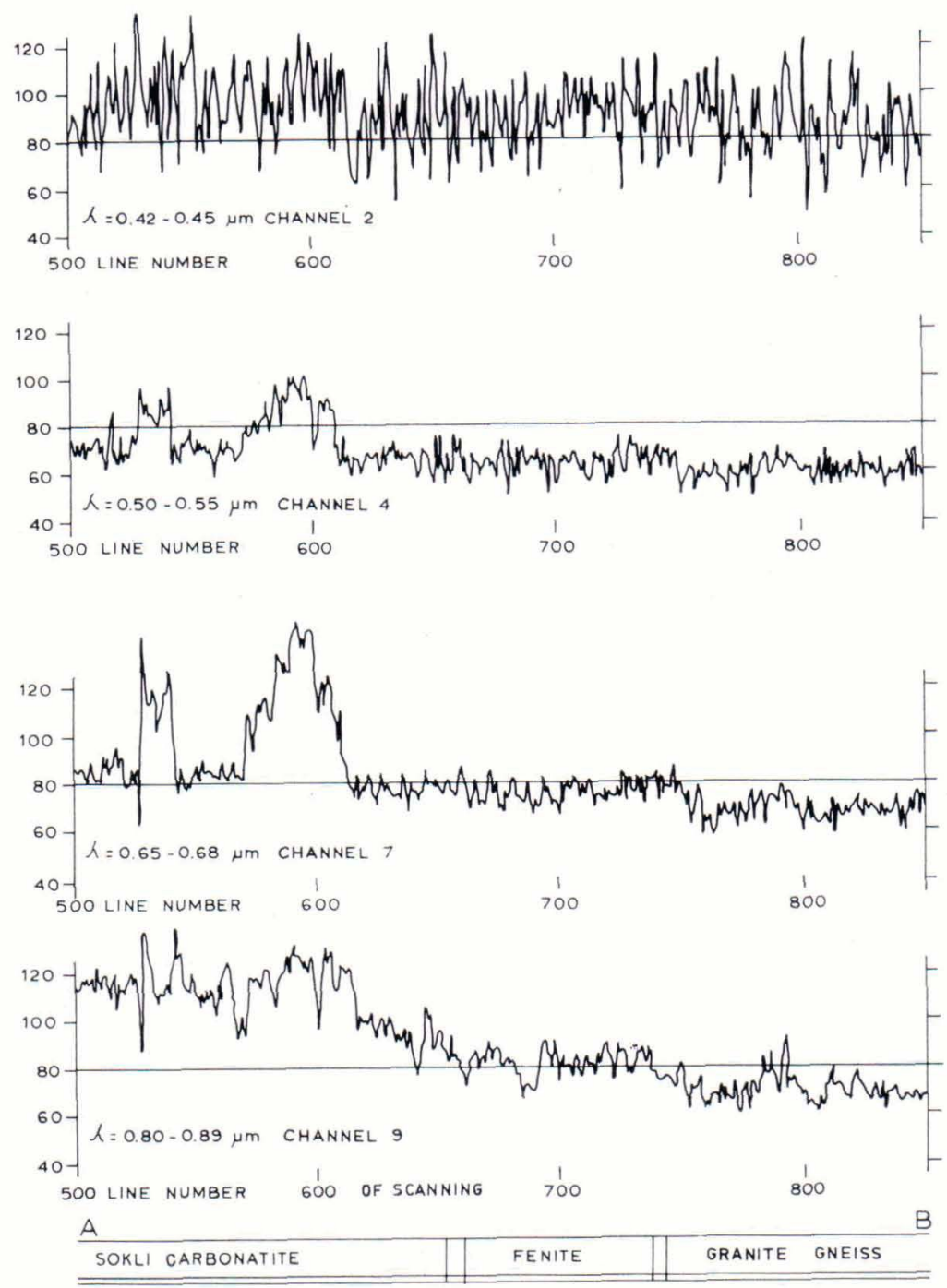

Fig. 4. Variation in radiation intensity in channels 2, 4,7 and 9 along column No. 349 of data coordinates. Corresponding geological profile has been appended to lower part of picture. 


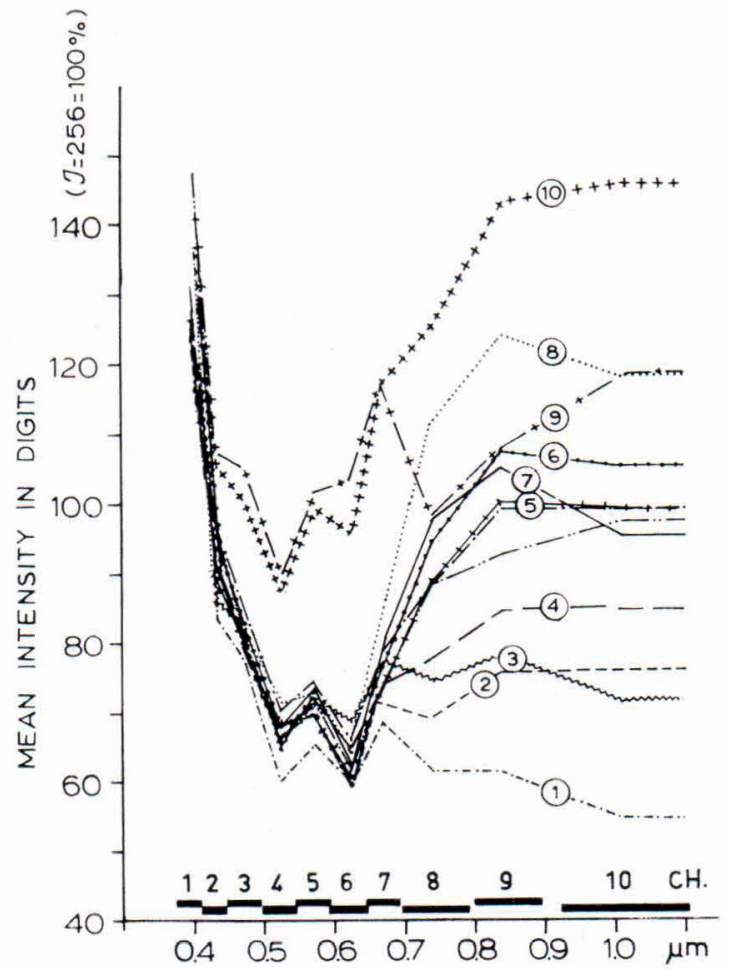

Fig. 5a. Mean of radiation intensity of training fields $1-10$ (cf., Table 2) as function of wave length. Ten channels used are indicated on the $\mathrm{X}$-axis.

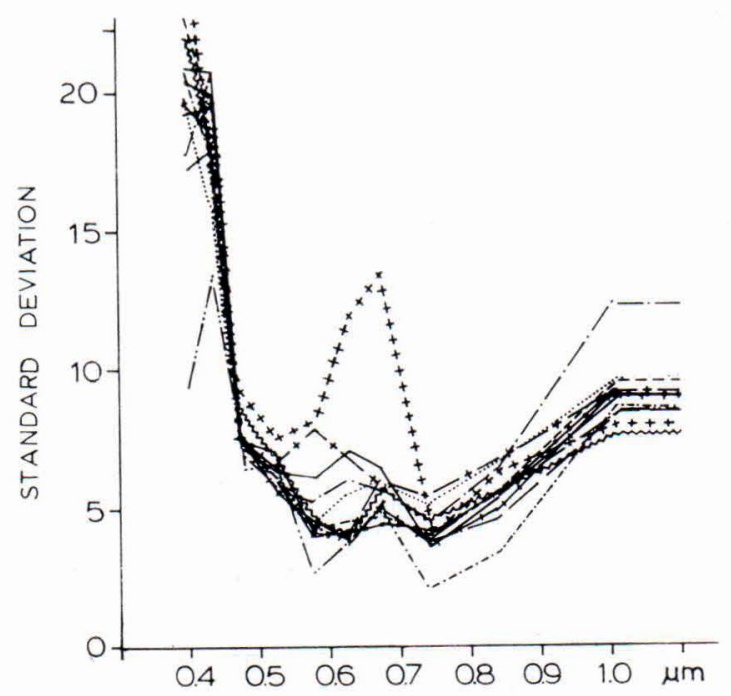

Fig. 5b. Standard deviation of the intensity of training fields $1-10$ from the mean intensity indicated in Fig. 5a. botanical classification all the way to the angle values $\frac{\psi}{2}=35^{\circ}$. The error induced on the intensity level of the radiation of the scanning geometry by angle values greater than this was too large, distorting the classification.

\section{Bedrock}

The bedrock is throughout overlain by soil, as a consequence of which the knowledge about it is based on ditching, drillings and geophysical measurements. The bedrock map is reproduced in Fig. 6. It is easy to divide the bedrock lithologically into two categories:

1. Silicate rocks (granite gneiss, ultrabasics, amphibolite, fenite).

2. Carbonatite complex (carbonatite, regolithic phosphorus ore).

The former, with the exception of the fenite, are Precambrian, and the latter Caledonian-Appalachian in age (Vartiainen and Woolley 1974). Preglacial weathering of the bedrock surface is to be found in situ, providing evidence that the erosive effect of the continental ice sheet has been weak.

\section{Training or reference fields and radiation intensity}

Fig. 4 presents the geological profile of the bedrock and the corresponding variation in the radiation intensity from channels $2,4,7$ and 9 . The figure indicates that the variation in intensity on the band width $0.80-0.89 \mu \mathrm{m}$ (channel 9) reflects most accurately the geological variation, upon which the carbonatite complex represents the highest level of intensity and the gneissose granite the lowest. As the wavelength shortens, this correlation weakens and on shorter wavelengths (channel 2) scattering in the atmosphere presumably 
Table 2. Training fields and their geology.

\begin{tabular}{|c|c|c|}
\hline Class No & Bedrock class & Overburden \\
\hline 1 & Gneissose granite & Till \\
\hline 2 & Ultrabasic rock & $»$ \\
\hline 3 & Fenite, low grade & $»$ \\
\hline 4 & Fenite & $»$ \\
\hline 5 & Carbonatite & Sand and till \\
\hline 6 & $\gg$ & Till \\
\hline 7 & Phosphate rock & $»$ \\
\hline 8 & $»$ & ” \\
\hline 9 & $»$ & Bog \\
\hline 10 & Carbonatite & Bog \\
\hline
\end{tabular}

causes so much background noise that its use for classification purposes cannot come into consideration. The spectral range of red near-infrared proved in the present material to be the most suitable for classification. The training fields for supervised classification were selected according to the bedrock geology, as shown in Table 2. The number of ground elements in each class was about fifty.

The mean intensities of the radiation received from ten training fields numbered in Table 2 are shown in Fig. 5 a. From this figure, we can see that on wavelengths of 0.65 $\mu \mathrm{m}$ and longer the classes can be discriminated best from each other, especially when we take into account the deviation presented in Fig. 5 b. Further, it can be noted that the classes of silicate rocks (1-4) belong to low intensity classes compared with the classes of the carbonatite complex $(5-10)$.

It is possible on the basis of Table 2 and Figs. 6 and 7 to estimate the effect of the quality of the overburden on the intensities. The till-covered carbonatite complex is represented by classes $6-8$. If the cover consists also of glaciofluvial material, sands, as in class 5 , the intensity decreases, though not to the extent of the classes of the till-covered silicate rocks. If there occurs an open bog in the carbonatite complex, the intensity rises, as in classes 9 and 10 .

\section{Classification}

A three-channel combination 7,8 and 10 was used for supervised pattern recognition of the ten classes. The result is presented in Fig. 7.

When the validity of the classification is examined (cf., Fig. 6), it may be noted:

1. Silicate rocks fall into classes $1-4$ almost to a $100 \%$ extent.

2. Classes $6,8,9$ (orange, black and gray, respectively) contain rocks of the carbonatite complex to an extent of over $90 \%$, and classes 8 and 9 indicate specifically the location of phosphorus ore. These classes are thus of critical importance from the ore-prospecting standpoint.

3. Classes 5 and 7 (greens) are spectrally situated between the classes consisting of silicate rocks and the carbonatite complex (Fig. 5). Thus areas belonging to both geological complexes fall into these classes. On the other hand, the spectrally close Class 6 indicates carbonatite exclusively. Class 10 (yellow) is the class of open and luxuriant bogs related mainly to the carbonatite.

4. The main shortcoming of the classification presented in Fig. 7, when it is enlarged (scanned area totals $500 \mathrm{sq} . \mathrm{km}$ ) so as to extend into the silicate rock area of the surroundings, is in the fact that no training fields, separate classes, have been taken from the bogs occurring above the silicate rocks. Accordingly, these bogs remain, on the basis of the tests, unclassified or fall largely into classes 5 and 7 (greens) - that is, they fall mainly into classes of lower intensity than the bogs of the carbonatite complex ( 9 and $10)$.

\section{Classification and vegetation}

As noted previously, the radiation used is reflected by the vegetation and therefore 




Fig. 7. Automated and supervised classification result, a TV-display. The classes (cf. Table 2 and Fig. 5) 1-11 are indicated by the following color 1 brown, 2 blue, 3 red, 4 pink, 5 light green, 11 white/unclassified. Threshold $1 \%$. Picture unrectified. 

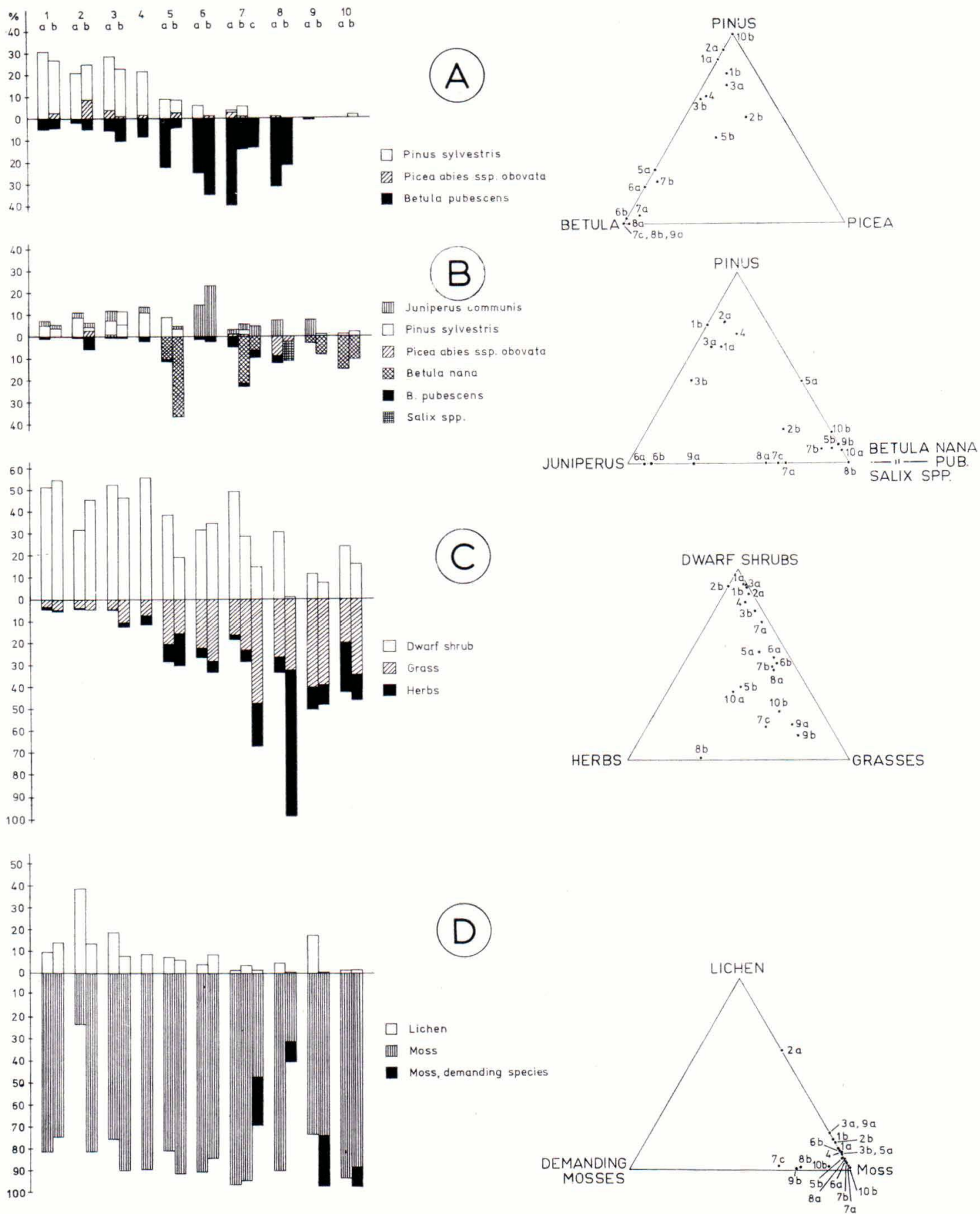

Figs. 8A-D. Density of tree layer (A), shrub layer (B), field layer (C) and bottom layer (D) as percentages of area of test fields. Each spectral class, 1-10, has been subdivided, a, b; except Class 7 , $\mathrm{a}, \mathrm{b}, \mathrm{c}$. Alongside each columnar diagram is a corresponding triangular diagram of densities. 
Table 3. Spectral-geological classes $1-10$ and their botanical subdivision according to Fig. 8 as well as the forest an bog types corresponding to the subclassification.

\begin{tabular}{|c|c|c|}
\hline $\begin{array}{l}\text { Class No } \\
\text { and subdiv. }\end{array}$ & $\begin{array}{l}\text { Number } \\
\text { of test } \\
\text { fields }\end{array}$ & Forest or bog type \\
\hline $1 \stackrel{\mathrm{a}}{\mathrm{b}}$ & $\begin{array}{l}6 \\
8\end{array}$ & $\begin{array}{l}\text { Empetrum-Vaccinatum } \\
\text { Empetrum-Myrtillus }\end{array}$ \\
\hline $2 \underset{\mathrm{b}}{\mathrm{a}}$ & $\begin{array}{r}11 \\
4\end{array}$ & $\begin{array}{l}\text { Cladina and Calluna-Cladina } \\
\text { Empetrum-Vaccinatum }\end{array}$ \\
\hline $3 \stackrel{\mathrm{a}}{\mathrm{b}}$ & $\begin{array}{l}9 \\
9\end{array}$ & $\begin{array}{l}\text { Empetrum-Vaccinatum (-Myrtillus) } \\
\text { Uliginosum-Empetrum-Myrtillus }\end{array}$ \\
\hline 4 & 6 & Uliginosum-Empetrum-Myrtillus \\
\hline $5 \stackrel{\mathrm{a}}{\mathrm{b}}$ & $\begin{array}{l}8 \\
8\end{array}$ & $\begin{array}{l}\text { Uliginosum-Empetrum-Myrtillus } \\
\text { Like } 5 \text { a but becoming peat-covered }\end{array}$ \\
\hline $6 \begin{array}{l}\mathrm{a} \\
\mathrm{b}\end{array}$ & $\begin{array}{l}9 \\
5\end{array}$ & $\begin{array}{l}\text { Uliginosum-Empetrum-Myrtillus } \\
\text { Hylocomium-Myrtillus }\end{array}$ \\
\hline $7 \stackrel{\mathrm{a}}{\mathrm{b}}$ & $\begin{array}{l}2 \\
7 \\
4\end{array}$ & $\begin{array}{cc}\text { Between types } 5 \mathrm{a} \text { and } & 6 \mathrm{~b} \\
-»- & , \text { swampy } \\
-»- & , \text { boggy }\end{array}$ \\
\hline $8 \stackrel{\mathrm{a}}{\mathrm{b}}$ & $\begin{array}{r}10 \\
6\end{array}$ & $\begin{array}{c}\text { Hylocomium-Myrtillus } \\
-»-\text {, swampy }\end{array}$ \\
\hline $9 \begin{array}{l}\mathrm{a} \\
\mathrm{b}\end{array}$ & $\begin{array}{l}10 \\
12\end{array}$ & $\begin{array}{l}\text { Meadow } \\
\text { Pine, tall sedge and flood bogs }\end{array}$ \\
\hline $10 \begin{array}{l}\mathrm{a} \\
\mathrm{b}\end{array}$ & $\begin{array}{r}13 \\
9\end{array}$ & $\begin{array}{l}\text { Open bog } \\
\text { Open - pine bog }\end{array}$ \\
\hline
\end{tabular}

primarily transmits data on the variations in vegetation. There was thus reason to determine what sort of vegetation prevails in the area embracing ten classes represented in Fig. 7.

Taken as the starting point of the investigation was the space covered in the test field by each species of plant. The vegetation was divided into four layers in the order in which, viewed from the air, they covered the ground and each other: 1. tree layer, 2. shrub layer, 3. field layer, 4. bottom layer. These layers were investigated separately in test fields measuring $10 \times 10 \mathrm{~m}^{2}$. There were altogether 158 such fields, which were located in different parts of the region investigated (Figs. 8 a-d).

Fig. 8 a shows the extent of ground covered by the tree layer. It shows that conifers (Pinus sylvestris) predominate in the classes of silicate rocks, $1-4$, and the birch (Betula pubescens) is predominant in classes $5-8$ of the carbonatite complex. Classes 9 and 10 of high intensity are treeless. The occurrence of birch in itself cannot be taken as an indicator of the carbonatite complex, though, perhaps, its heavy density, and specifically its appearance in heathy tracts may be significant. The increase in the density of the birch and the decrease in pine from Class 1 to Class 8 appears to follow the growth in the intensity of near-infrared radiation (cf., Fig. 5).

In Fig. $8 \mathrm{~b}$ is represented the density of the shrub layer in the test fields. It can be noted that in the classes of silicate rocks a slight schrub layer is composed by Pinus sylvestris, Betula pubescens and Juniper communis. Typical features of the carbonatite complex classes are Juniper communis and Betula nana. As species, these do not indicate the carbonatite complex, either, though evidently with respect to the density of occurrence of the species.

Fig. 8 c represents the density of the field 
Table 4. Species indicating exceptional luxuriance as density percentages met with in test fields $5 \mathrm{~A}-10 \mathrm{~B}$. Among the ones found outside the test fields but within the carbonatite complex, mention might further be met of Brunus padus, Rubus saxatilis and Saussurea albina.

\begin{tabular}{|c|c|c|c|c|c|c|c|c|}
\hline Class index & $5 a$ & $5 \mathrm{~b}$ & $6 \mathrm{~b}$ & $7 \mathrm{c}$ & $8 \mathrm{~b}$ & $9 a$ & $9 \mathrm{~b}$ & $10 \mathrm{~b}$ \\
\hline Selaginella selaginoides & 1 & - & - & + & - & 3 & - & - \\
\hline Equisetum scirpoides & + & - & + & - & - & - & - & 二 \\
\hline Carex capitata & - & - & - & 5 & - & - & - & - \\
\hline Moehringia lateriflora & 1 & - & - & - & - & - & - & - \\
\hline Thalictrum simplex & - & + & - & + & 17 & - & - & - \\
\hline Saxifraga hirculus & - & - & - & - & - & - & - & 3 \\
\hline Cirsium helenioides & - & 1 & - & - & 45 & + & - & - \\
\hline Sphagnum subsecundum & - & - & - & - & - & - & 8 & - \\
\hline S. teres & - & - & - & 1 & - & - & - & - \\
\hline S. warnstorfii & - & - & - & 15 & - & - & 20 & 55 \\
\hline Campylium stellatum & - & - & - & 13 & - & - & - & - \\
\hline Paludella squarrosa & - & - & - & - & - & 25 & - & 5 \\
\hline Tomenthypnum nitens & - & - & - & 1 & - & - & 15 & 7 \\
\hline
\end{tabular}

layer. The species are divided into three groups: 1. dwarf shrubs, 2. grasses, 3. herbs. The silicate rock classes are characterized by an abundance of dwarf shrubs and a sparseness of grasses and herbs, whereas in

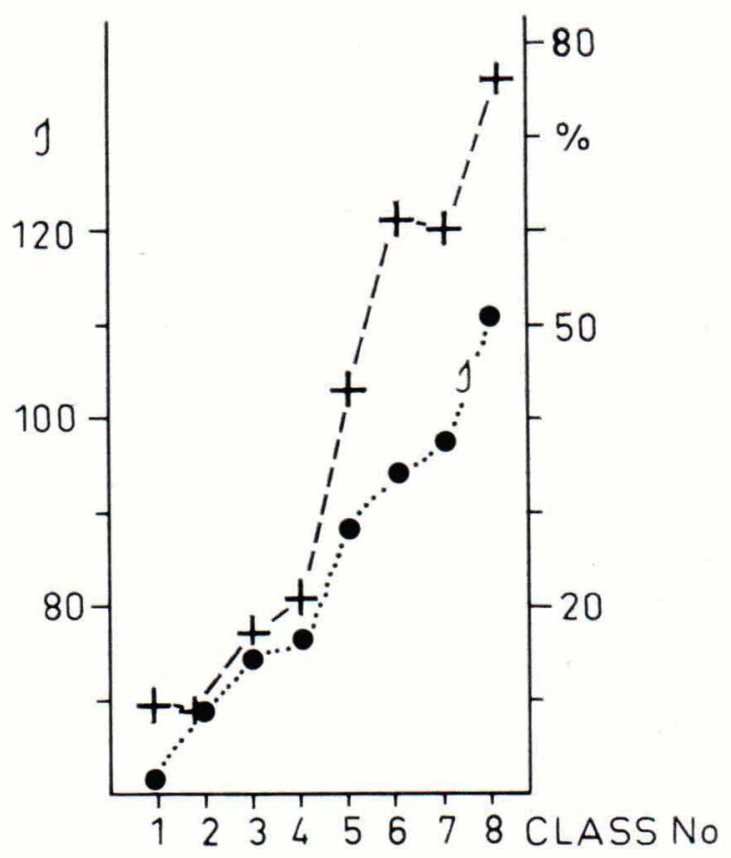

Fig. 9. The increase in luxuriance of vegetation from Class 1 to Class 8 (crosses) and the corresponding increase in radiation intensity of channel 8 (dots). The crosses show the sum of the density of the birch, grasses and herbs. the carbonatite complex classes the situation is the opposite, exhibiting relatively more luxuriant growth. It is to be noted that this luxuriance increases from Class 1 to Class 8 in relation to the growth in the intensity of near-infrared radiation (cf., Fig. 5).

Correspondingly, in Fig. 8 d are represented the species of the bottom layer. The species indicated above the horizontal line, Cladonia for instance, thrive on the silicate rocks but not on the carbonatite complex.

In Table 3 are presented the forest and bog types corresponding to Fig. 8. Listed from the least fertile (dry heath, cf. Table 1) to the most luxuriant (moist heath), the forest types are: 1. Cladina and Calluna-Cladina, 2. Empetrum-Vaccinatum, 3. EmpetrumMyrtillus, 4. Uliginosum-Empetrum-Myrtillus, 5. Hylocomium-Myrtillus. Of these, the first three occur only in the classes of silicate rocks and Hylocomium-Myrtillus only in carbonatite complex classes 6 and 8 . The forest type Uliginosum-Empetrum-Myrtillus, listed fourth, occurs in intermediate classes, but in the carbonatite complex classes it is more luxuriant in its growth. Of the forest types occurring in small patches in the region, mention should be made of Ledum-Uliginosum and Geranium-Vaccinium, the latter of 


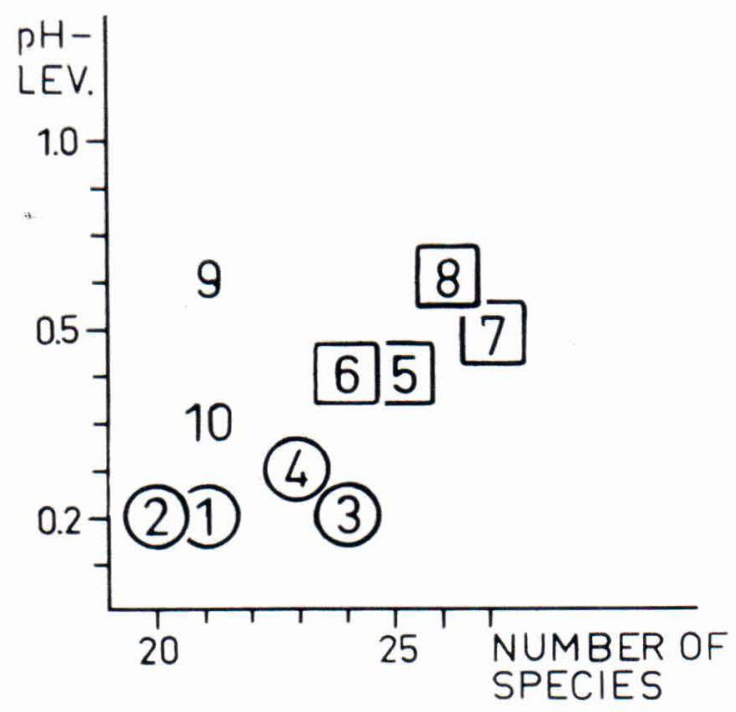

Fig. 10. Number of species and $\mathrm{pH}$ level by classes (spectral classes 1-10) obtained from investigation of 158 test fields. The $\mathrm{pH}$ level was calculated: $\mathrm{ph}_{\text {measured }}$ minus $\mathrm{pH}_{\text {constant. }}$

which can also be regarded as an indicator of the carbonatite complex. In the classification, there is no point of comparison for the silicate rock bog types; but it is noteworthy that also dry and open meadows fall into Class 9 of the bog types.

Only the most luxuriant forest type in the classification, Hylocomium-Myrtillus, can be regarded as an indicator of the carbonatite complex in this area located north of the Arctic Circle. It represents at the same time tracts of heath, from which the reflected radiation intensity was the highest in the channel combination used. An increase in luxuriance of vegetation and intensity of radiation could be observed previously (Fig. 9) as an increase in the density of birch (Betula pub.) as well as of grasses and herbs and in a decrease in pine shading the latter (as viewed from an aircraft). The pine is perceptibly weaker than the other types of vegetation mentioned as a reflector of infrared radiation.

The plant species indicating exceptional luxuriance, which are met with in the area of the carbonatite complex, are a different matter. Species in this category are listed in Table 4.

Fig. 10 shows that the average number of species met with in the area of silicate rocks (Classes 1-4), as well as its $\mathrm{pH}$ value, are lower than in the classes $(5-8)$ of the carbonatite complex. The $\mathrm{pH}$ of the bogs belonging to the carbonatite complex is likewise rather high (Classes 9 and 10).

The training fields of this classification were selected on geological grounds. On the other hand, there would be reason to try selecting training fields on the basis of vegetation types or the primary factor of geobotanical prospecting and comparing the classification result thereby obtained with the geology. In any event, the foregoing result of remote sensing connects also the bedrock components of a covered area as contributing factors with the geobotanical prospecting result. In the multidiscipline sense, the results bring together botanical, forestry, geological and even ore-prospecting interests. It is another story how collaboration of such a broad scope can be organized on a practical basis.

\section{Conclusions}

The dry heath vegetation reflects a minimum amount and the moist heath vegetation a maximum amount of radiation. The type of vegetation is largely dependent on the superficial geology and therefore the latter can be classified indirectly by means of remote sensing. In certain cases it is possible that also the lithology, though unexposed, regulates the type of vegetation above and can be prospected. So in Lapland (Sokli area), where the climatic stress is strong, the moist heath type Hylocomium Myrtillus (HMT) was a reliable indicator for the carbonatite complex and the most luxuriant HMT in- 
dicated the phosphorus ore. The vegetation types above silicate rocks were less luxuriant. The classification of the bogs in Sokli remained inadequate.

Acknowledgements - Mr. M. Heikkinen, undergraduate of botany, carried out the botanical field mapping. He and his teacher, Professor P. Havas, of the University of Oulu, willingly gave their

\section{References}

Kilpelä, E., Jaakkola, S., Kuittinen, R. and Talvitie, J. (1978) Automated earth resources survey using satellite and aircraft scanner data, a Finnish approach. Technical Research Centre of Finland, Publication 15, 70-105.

Vartiainen, H. and Woolley, A. R. (1974) The age assistance as experts. Fruitful discussions were held on matters pertaining to the bedrock with Dr. J. Nuutilainen and Messrs H. Vartiainen and T. Vuotovesi, geologists on the staff of the Rautaruukki company, as well as on matters pertaining to the deposits overlying the bedrock with Professor K. Kauranne and Messrs P. Lehmuspelto and R. Haimi, geologists on the staff of the Geological Survey of Finland.

of the Sokli carbonatite, Finland, and some relationships of the North Atlantic alkaline igneous province. Bull. Geol. Soc. Finland 46, $81-91$.

Manuscript received, April 10, 1979 